\title{
Kadın İmgesi ve Tarih Boyu Değişimi
}

\author{
Öğr. Gör. Naciye Derin Işıkören
}

\section{Öz}

Görsel sanatlar eğitimi, kısmi olarak, tarihte ortaya konmuş görsellerin incelenmesini kapsamaktadır. Görseli yapılandıran elemanların araştırılması, görseli anlamak için gereklidir. Sanat öğrencilerinin, bu esası kavramaları önemlidir. Bu çalışma "Hangi koşullar altında bir imge dönüşüme uğrar?" sorusunu örneklendirmek üzere "dönem/ideal kadın imgesi bağlantısı ve dönemin geçerli sayılan değerlerinin, imgeyi yapılandırıcı etkisi"ne odaklanmıştır. Tarih sürecinde, ideal kadın imgesi, sabit özellikler göstermemektedir. Söz konusu imge değişimleri, ait olduğu dönemin geçerli toplumsal değerlerinin, inancının ve gelişen teknolojisinin izlerini taşır. Dönem sanatçıları tarafindan, bu değerler ve teknolojik olanaklar doğrultusunda oluşturulmaktadır.

Anahtar kelimeler: İdeal kadın imgesi, Toplumsal değerler, Kolektif bilgi, Algı, Görsel sanat eğitimi.

\section{WOMAN IMAGE \& ITS TRANSFORMATION IN HISTORY}

\begin{abstract}
Visual arts education is partially includes studying the art works that had become masterpieces throughout history. Searching for the elements that create the work of art, can be considered as necessary to understand the art work. This notion has to be internalized by visual art students. In that sense, this study is an attempt to answer the question "how and under which effects a sign changes throughout time?" by focusing to the "Ideal Woman Image". Throughout history, ideal woman image, does not display a fixed structure. The image changes, in terms of structure and meaning within the time period's administrative, religious values and technology. Hence, created and interpreted by that time period's artists according to those values. In that sense, this study is an attempt to search the link between period/ideal woman image in accordance with that time period's dominant values.
\end{abstract}

Keywords: Ideal woman image, Social values, Collective knowledge, Perception, Visual art education. 


\section{Giriş}

Görsel sanatlar eğitimi, kısmi olarak, tarih boyu, sanatçılar tarafından oluşturulmuş imgelerin araştırılarak öğrenilmesini gerektirir. Yeni imge ve görsel kompozisyonlar üretmeyi öğrenmek ise bir diğer kısmını oluşturur. Öğrenim süreci içerisinde, imgenin yer aldığı zaman aralığına bağlı olarak, etkilendiği sosyal ve teknolojik unsurları araştırmak gerekmektedir. Sözkonusu araştırma, imgelerin doğru yerde ve anlam içeriğinde kullanılabilmesi ve doğru okunabilmesi açısından önemli olabilir. Bu fikri destekleyici örnek bir çalışmanın, "Neden ve hangi koşullar altında bir imge değişime ve dönüşüme uğrar?" sorusuna dayandırılarak yapılması uygun olur. Bu sebeple, bu çalışmada, "etki altında değişime uğrayan görsel birim" olarak "ideal kadın imgesi" seçilmiştir.

"Kadına özgü zerafet" (Eco, 2006: 14), çok çeşitli anlam içerikleri ileçeşitli dönemlerde, ideal görüntüleri ile yansıtılmışır. Dönemine göre ideal kabul edilen kadın görüntülerinin, biçimsel ve çizgisel olarak sergilediği farklılıkları, Umberto Eco'nun "Güzelliğin Tarihi" adlı kitabında bulunan tablo ve heykel dizinlerinde gözlemek mümkündür. Ardı ardına dizilmiş olan tablo ve heykeller, M.Ö. XXV. yüzyıldan, M.S. 2000 yılına kadar yer almış kadın görsellerini içermektedir (Eco, 2006: 16-19).

Her dönemde popüler olan, ancak farklı anlamlar taşıyacak şekilde görselleştirilen ideal kadın imgesinde gözlenebilen değişkenlik, döneme ait toplumsal ve teknolojik etkileşimin bir göstergesi olarak düşünülebilir. $\mathrm{Bu}$ dinamiğin tersine bir hareketle, söz konusu imge, ortaya konduğu andan itibaren, bu etkenlerden biriolarak görülebilir. Araştırma dâhilinde, söz konusu döngüyü, örneklerle ortaya koymak üzere, tarih boyu çeşitli ortamlarda yer almış ideal kadın imgelerinin, dönemlere göre içerik analizi yöntemi kullanılarak bir serimi yapılacaktır. Görsellerin değişimini etkileyen faktörlerin izlerini yansıtan kompozisyon yapısı ve öğeleri incelenecektir. Inceleme, ilkel çağ toprak figürinlerinden başlayarak, günümüz reklam görsellerine uzanacaktır.

Araştırmanın sorgulama odağı, ideal kadın imgesinin neden değiştiği değil, nasıl ve neye göre değiştiğiniörneklendirerek ispatlama çabasıdır.

\section{İmgenin, Görsel Kompozisyonu Oluşturma ve Okuma Sürecinde Değeri}

Görüntüsel ve yoğrumsal göstergeyi kendi bağlamları içinde anlamlandırmak, düzanlamsal okumaların yanında yapılabilecek bir yananlamsal okuma yapmayı gerektirir. Farklı amaçlarla hazırlanmış, belirli bir ideolojisi olan yapıtların değerlendirilmesinde; toplumsal değerler, gelenek-görenek, ideoloji, toplumsal 
bellek gibi farklı artalan bilgisine gereksinim duyulabilir. Sorun sanatsal yapıtların değerlendirilmesi ise düzanlamsal okumanın yanında yapılması gereken zorunlu bir yananlamsal okuma süreci de gereklidir (Günay, 2008: 14).

$\mathrm{Bu}$ çerçevede, imgeyi anlama ve anlamlandırma süreçlerinde, onu çevreleyen, sosyal değerler, yönetsel kontroller ve üretim imkânları yapılandırıcı unsur olarak görülebilir; imgenin ortak bilgi içerisinde yerini etkileyebilir. Aynı zamanda, imge herhangi bir kompozisyon içerisinde kullanıldığında, kompozisyonun ilettiği görsel mesaj, yine bu değerler doğrultusunda anlam kazanabilir ve algılanabilir. Görsel mesaj okuma ve görsel mesaj oluşturma süreçlerinde, imgelerin dönemlere göre yansıttığı anlam ve görüntü değişim ve dönüşümlerine, tarihten günümüze uzanacak örnek bir çalışma oluşturmak üzere "ideal kadın imgesi" uygun bir örnek olarak kabul edilebilir; çünkü, yukarıda belirtildiği gibi dönemler boyu süreklilik arz etmektedir. Görsel sanat eğitmen ve öğrencilerinin imge/ sosyal değerler bağlantısını, imgeyi anlamlandırma ve anlamlı görsel mesajlar oluşturma bakımından sürekliliği olan bir örnekle okuyabilmeleri, kavrayış düzeyini artırır. Bir imgenin oluşumunu anlama çabası, söz konusu imgenin kompozisyonu ve görsel mesajı bakımından analiz edilmesininyanı sıra, imgeyi çevreleyen koşulların da analizinin gerekliliğine işaret eder.

\section{Yapı İçerisinde Bir Birim Olarak Kadın İmgesi}

Yukarıda belirtilen yaklaşım, göstergebilim teorileri ile desteklenebilir. Ferdinand de Saussure, dili "Koşulları sadece anlık düzenlemelerle belirlenen saf değerler sistemi" olarak tanımlar (Saussure, 1966: 116). Anlamlı bir birimden bahsetmek ancak sözcüğün kimliği ve değeri ile birlikte dikkate alınmasıyla mümkün olabilir. Bir birimin kimliği sabit değildir, farklı cümlelerde tekrarlandığı her seferde değişir, hatta farklı tonlamalarla bile değişebilir. Saussure'e göre, "Bir birimin değeri onu çevreleyen diğer birimlerce atfedilmekte ve belirlenmektedir" (Saussure, 1966: 117). Öyle ise, sözcüğün ya da terimin değeri, dilin yapısı içerisindeki yeri ile ilişkili olarak var olabilir.

Bir sözcüğün ya da terimin değerini tanımlayan, diğer terimlerin varlığıdır. Aynı dil içerisinde, ilgili fikirleri ifade etmek için kullanılan tüm sözcükler birbirlerini karşılıklı olarak sınırlandırır. Sözcükler ancak farklılıkları yoluyla değer kazanırlar (Saussure, 1966: 116-117).

Bu bağlamda, bir sözcüğün karakterini, değerini belirleyen ve buna göre bir birim olarak tanımlayan, sözcüğün diğer sözcüklere göre konumlanışı olarak düşünülebilir. Prof. Dr. V. Doğan Günay, bu olguyu “Görsel OkurYazarlık ve Imgenin Anlamlandırıması" adlı makalesinde şu şekilde tanımlamaktadır 
"Saussure'ün "Anlam karşıtlık içinde doğar" ilkesi ile Hjemslev'in "anlam karşıtlıklarlaoluşur" ilkesi çözümlemeler için önemli bir çıkış noktasıdır" (Günay, 2008: 9).

Roland Barthes, benzer bir akıl yürütmeyi dil dışındaki çeşitli sistemlere uygular. Bu sistemler arasında trafik, moda, yiyecek sayılabilir (Barthes, 1957: 112). "Mitolojiler" adlı çalışmasında değer, yer ve anlam sürecine şu şekilde işaret eder, "Imleyen ve imlenen, ilki ve sonuncusu, üçüncü nesnenin yani işaretin bir araya getirilmesinden ve oluşturulmasından önce de vardır. Örnek olarak, var oluş düzleminde, gülleri, taşıdıkları mesajdan ayıramayacağımı söylemek ne kadar doğruysa, analiz düzleminde, belirten olarak güller ile işaret olarak gülleri birbiriyle karıştıramayacağımı söylemek de o kadar doğrudur" (Barthes,1957: 112). Bu anlamda, tüm işaretlerin, bulunduğu yere göre, manası sürekli değişen bir sözcükten farklı olmadığı düşünülebilir.

Semboller, işaretler, imgeler, aynı yazınsal dilde olduğu gibi, içinde konumlandıkları diğer kompozisyonel öğeler, dahası içinde yer aldığı kompozisyonun konumlandığı coğrafya, yönetim, toplumsal değerler, teknolojik koşullar çerçevesinde anlam bakımından çeşitlenebilir. Görsel imge, dilde, "sözcük" için geçerli olduğu gibi "imleyendir", ancak imgenin "imlenen" i yukarıda belirtilen koşullara göre değişiklik gösterebilir.

Bu bağlamda, imgeyi anlamak için, geniş bir perspektiften bakmak ve yansıttığı birden fazla kapsamı kavramaya çalışmak gerekir. "ideal kadın imgesi" yüzeysel ve alt anlamları kavrayabilmek için, her türden insan üretiminde görülen sürekli değişimi incelemek bakımından uygun bir örnek olarak kabul edilebilir. İmge de, tıpkı dilde anlamı ve değeri, içinde yer aldığı metnin kapsamına göre değişen bir sözcük gibi, dönemden döneme, içinde yer aldığı toplumsal değerlere ve üretim olanaklarına göreli olarak,görüntü ve anlam bakımından değişmekte midir?

\section{İdeal Kadın İmgesinde Şekil ve Anlam Değişimleri}

Güzel tarihin farklı dönemlerine ve kültürlere bağlıdır demek istiyormuşuz gibi anlaşılabilir ve araştırmamız görelilikle suçlanabilir. Oysa bizim söylemek istediğimiz tam da budur işte. Bu araştırma Güzel'in hiçbir zaman mutlak ve değişmez olmadığı, aksine tarihsel çağına ve ülkesine bağlı olarak çeşitli biçimlere büründüğünü öngörüyor (Eco, 2006: 14). 


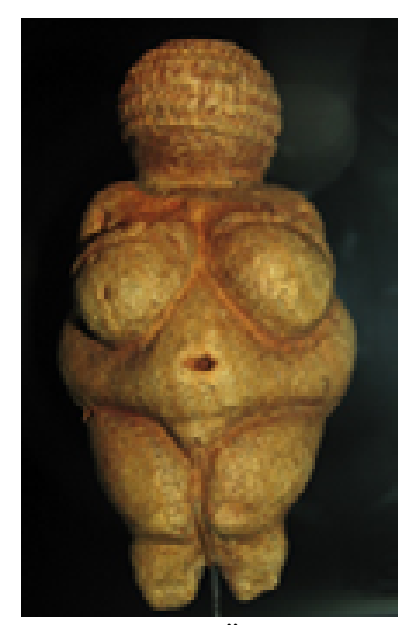

Resim I: Wilendorf Venüsü, M.Ö. 20000, Kireç Taşı, II cm

İdeal kadın imgesinin özgün görüntüsü, her ne kadar sanatçılar tarafından belirlense de, kural ve kaideler çerçevesinde şekillendirilmiştir. Paleolitik çağdan başlayarak, kadına, bulunduğu zamana ve ait olduğu topluma göre değer bakımından neyin önemli olduğunu gösteren farklı pek çok biçim ve anlam yüklenir. Paleolitik doğurganlık heykelciği ya da "Venüs adı verilen heykelcikler, doğurganlık, üreme ile ifade edilmiş olan hayatta kalma intiyacını temsil etmektedir"(Gimbutas,1989: 2). Bu dönemde, kadın tasvirinin, sonraki nesilleri besleyen ve yetiştiren varlık olarak sunulduğu düşünülebilir. Aynı zamanda, dünyada insanlığın var olmasının temel nedenini oluşturan, doğurganlığı içeren bir hayatta kalışı ifade ettiği de söylenebilir.

Bu olguyu, Gimbutas şu sözlerle tanımlar:

Eski Avrupa'da, inancın odak noktası, tarım ve hayvan yetiştiriciliğinin yanı sıra doğum, bakım, büyüme, ölüm ve üremeyi kapsıyordu. Bu dönemin insanları vahşi doğa güçlerine, yabani bitkilere ve mevsim döngülerine danışıyor ve tanrıçalara tapıyordu. Tanrıça imajları için genel bir sınıflandırma, hayat verme ve sürdürme, ölüm ve yenilenme özelliklerine göre yapılabilir ... Varoluşun yayılmasını sağlayan "dişil güç" olmuştur (Gimbutas, 1989: 3).

Bu içeriğe bağıı olarak, figürinler, üreme ve besleme organları bakımından abartılmış bir görsellik sergiler. Resim 1'de gösterilen Venüs heykelciğinde gözlenebileceği gibi kalça ve göğüsleri, hiyerarşik olarak diğer tüm organlarından daha büyüktür, detaylı işlenmiş̧ir ve çıplaktır.

Mitolojide yer alan kadın figurleri de kadının makbul şeklinin toplum içinde sürekli değiştiğini kanıtlar nitelikte öne çıkar. Eski mitolojide, ideal kadın 
imgesi, üretken, doğurgan karakteri ile tasvir edilmektedir. Örnek olarak Venüs, Roma din ve mitolojisinde bitki örtüsü tanrıçasıdır. Daha sonra, ideal kadın (M.Ö. 3.yy) Yunan tanrıçası Afrodit ile tanımlanmaya başlamıştır. Imparatorluk döneminde ona Aeneas'ın annesi, doğurgan Venüs, şans getiren Venüs Felix, zafer getiren Venüs Victrix ve kadınların iffetinin koruyucusu Venüs Verticordia olarak tapınılmışır. Heykel alanında ünlü Afrodit ya da Venüs örnekleri Melos ya da Milo Venüsü'dür (Louvre) ${ }^{1}$

Taşıdığı görsel özellikler bakımından ilk figürinler kadar sade olmamakla beraber yine çıplaktır ve kalça, gögüs kısımları orantısal olarak küçülmüştür ancak, çok daha detaylı, orantılı işlenmiştir.

M.Ö. 520 ile 420 yılları arasında, beşinci yüzyılın sonlarına doğru, Venüs Victrix'in ortaya çıkması ile tanrıça heykellerine atfedilmeye başlanan sanatsal değerle birlikte, heykellerin orantıları ve iş̧̧iliği de değişmeye başlamıştır. Artık bu heykellerin dini fonksiyonları tek ilgi alanı değildir. Heykeller sanat eseri olarak da değer kazanmaya başlamıştır. Yunan sanatının çeşitliliğindeki artış, Atina ve Yunanistan'ın zenginliklerine M.Ö. 408' de, Spartalılartarafından el konulmasına kadar, toplumunzenginleşmesi ve farklı sanat ve stil okullarının sayısının artması ile eş zamanlı olarak gerçekleşmiştir (Gombrich, 1980: 101).

Hıristiyanlığın ilk dönemlerinde, baskın dinin (Pagan dininden Hıristiyanlığa) değişmesi ile birlikte, kadın imgesi bir kez daha farkı bir şekil almaya başlamıştır. Venüs yerini, Meryem ve Maria Magdalenatasvirlerine bırakmaya başlamış, kadın imgesi bir kez daha dini bir figür haline gelmiştir. Miladi 311 yilında, Imparator Konstantin, Devlet organı olarak Hıristiyan Kilisesini kurmuştur. Bu olay sanat, sanatçı ve kilise arasındaki tüm ilişkiyi değiştirmiştir çünkü bundan önce yasal ibadet yerleri oluşturmak mümkün değilken, yasal hale gelmiştir (Gombrich, 1980: 133134).

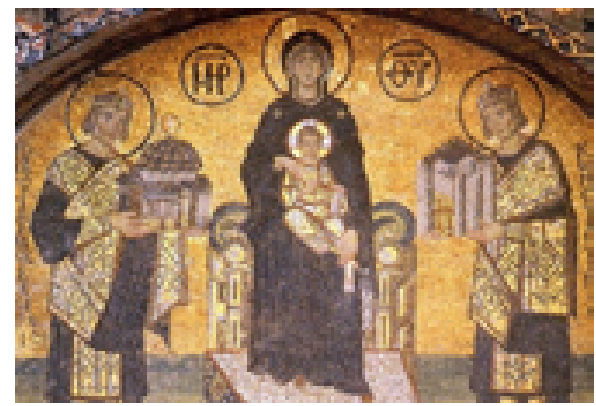

Resim 2: Imparatoriçe Irene, Bakire ve Bebek Isa, M.S. III I, Mosaik $80 \mathrm{~cm}$ x $20 \mathrm{~cm}$, Aya Sofya

' Columbia Electronic Encyclopedia. (February, 2013), 6th Edition;, pl, Venus, in Roman religionandmythology. Web: http://connection.ebscohost.com/c/reference-entries/85548764/venus-roman-religion-mythology adresinden 15 Haziran 2015'te alınmıştır. 
Buna paralel olarak, tüm dünyaya ve inananlara paganizm ve hıristiyanlık arasındaki farkı göstermek adına, kiliseleri Pagan Tapınaklarından farklı bir şekilde inşa ve dekore etmenin büyük önem kazandığı söylenebilir. Bunun sonucunda M.S. 900 ile Orta Çağ arasında, "Bakire Meryem ve Çocuk" ya da "Meryem Ana" tasvirlerinin, Venüs tasvirlerinin yerini almaya başladığı gözlenebilir.

Orta Çağın sonlarına doğru, İtalya'dan yayılmaya başlayan Rönesans tarzı ve estetiğinin etkisinde ise büyük bir değişim daha yaşanmıştır.

1400'lü yılların başlarında dünya uyandı. Floransa, İtalya'da ilk ortaya çıkışından itibaren kültürel Rönesansya da Yeniden Doğuş, Roma ve Venedik'e, sonra da 1500'de (Kuzey Rönesans olarak bilinen) Avrupa'nın geri kalanınayayıldı... Görüntü bakımından değişen ortak unsurlar, Yunan ve Roma sanat ve edebiyatının yeniden keşfedilmesi, bedenin ve doğanın bilimsel çalışmalara konu olması ve doğa formlarının gerçekçi olarak taklit edilmek istenmesidir (Strickland, 1992: 32).

Söz konusu tarz değişikliğini besleyen bir dizi sosyal ve teknolojik etken olmuştur, örneğin Gutenberg'in 1446-50 yılları arasında, hareketli parçalarla yazı baskısını icat etmesi bu etkenlerden biri olarak sayılabilir. Bu gelişme, fikir ve sanat eserlerinin çoğaltılarak dağııımını ve dolayısıyla iletilerek, dolaşımını hızlandırmıştır.

Rönesans 1500-1600 yılları arasında Kuzey Avrupa'ya yayılmıştır. Bu süre zarfında, 1517'de Avrupa'da Martin Luther ve Protestan mezhebi oluşumunun başlangıçları görülmeye başlamıştır (Gilbert,1998: 417).

Keşfedilmiş ve keşfedilecek fazlasıyla yeni alan olması, tanımlanabilir bir tarz ve popüler estetik perspektifi kavramını beraberinde getirir.

Yönetsel bağlamda ise farklı gelişmeler, kadın görüntüsü değiş̧imini bir kez daha desteklemektedir.

Sanat hamiliği bakımından koşullar alışımadık biçimde olumluydu. İtalya ticaret ve bankacılığın yaygın olduğu güçlü bir şehir-devlet geliştirmişti. Bu ticaretin başında olan tüccar sınıfının üyeleri, harcayabilecekleri çok miktarda paraya sahipti, iyi eğitim almışlardı, prestij nedeniyle ve tabiatları gereği sanata yatırım yapmaya çok istekliydi. Ayrıca, Hıristiyan Kilisesinin merkezi de İtalya'da bulunuyordu ve hamilik eden diğer bir önemli kaynağı oluşturuyordu. Ayrıca, şekil ve form bakımından Rönesans'ın sanat üzerindeki etkilerinden biri resimde ve heykelde Greko-Roman motiflerin ve oranların, renk ve perspektifin yeni bir yorumuyla geri gelmesidir (Gilbert, 1998: 395). 


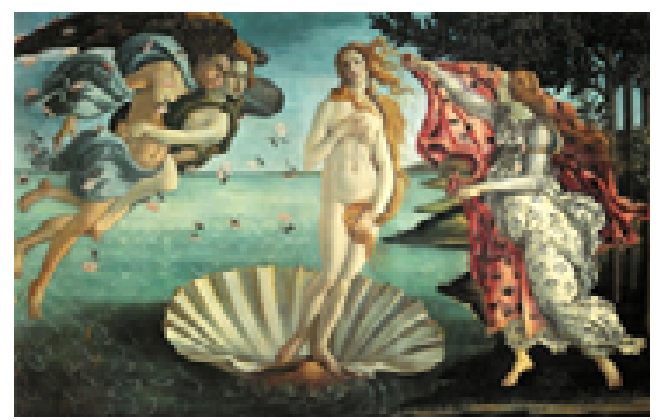

Resim 3: Sandro Boticelli, Venüsün Doğuşu, 1482- /486, Tuval üzerine Tempera, I72 x $278 \mathrm{~cm}$ Döneme ait koşullar içerisinde, ideal kadın imgesi, tarihsel zaman çizgisinde bir kez daha değişir, Venüs adıyla, çıplaklığıyla, ideal güzelliği ve mitolojisiyle geri dönmüştür; bunu Botticelli'nin 1480 tarihli “Venüsün Doğuşu" eserinde gözlemek mümkündür.

Rönesans'tan sonra, 1600-1750 arasındaki Barok ve Rokoko döneminde, Kilise kadın imgesinietkilemeye devam etmiştir. Rönesans'la gelen sınırlı bir serbestleşme olsa da, özneler hala dini ya da mitolojiktir, belli ölçeklerle sınırlıdır. "Krallar çağı" olarak adlandırılan 17. ve 18. yüzyılda bile, sanat bağlamındaki din etkisinin devam ettiği, eserlerde gözlenebilir.

Ancak, takip eden yüzyılda, endüstriyel devrimin etkisi ile farklı gelişmeler meydana gelecektir. Sanatın Öyküsü adlı kitapta, bu duruma şu şekilde işaret edilmiştir, "Başlangıcından bu yana sanatı ayakta tutan temeller çökmeye yüz tutuyordu. Sanayi devrimi, mekanik üretimi egemen kılarak el sanatları geleneklerini yıkmaya başlamıştı" (Gombrich, 1980: 395).

Rönesans ve Barok'tan farklı olarak, 19. yüzyılın "izm"leri, daha önceki yüzyıllarda görülen sanat akımları ile karşılaştıııldığında, daha kısa süreli olmuştur. Realizm akımına ve Gustave Courbet (1819-1877) tarafından dile getirilen manifestoya kadar, sanat dünyası ve bu dünyayı çevreleyen sosyal ve politik koşullar, Fransız devrimi, sona eren monarşiler ve oluşmaya başlayan demokrasiler gibi siyasi değişikliklerle dolu idi.

19. yüzyıl ortalarına gelindiğinde, bir Fransız sanat adamı ve entellektüeli olan Gustave Courbet, sergisinde dile getirdiği manifestosu ile sanatçılar için özgürlüğün kapılarını açmıştır.

Realizmin en tutarlı sanatsal ifadesi on dokuzuncu yüzyıl ortalarının Fransa'sında dile getirilmiştir. Kaynak olarak doğayı gören sanatçılar, sanatsal özgürlüğü ve kendini ifade etmeyi destekleyen Romantizm akımını izlemiştir. Takiben, Courbet, Realist Manifestosunda, kendi ilkelerinden sapmaksızın, sadece hoşa gitmek için resim yapmak istemediğini dile getirir. 
“Courbet'nin kolay etkileme yöntemlerine bilinçli olarak yüz çevirmesi ve dünyayı nasıl görüyorsa öyle verme kararı, birçoklarının önyargılardan kurtulmasında ve yalnızca içlerinden gelen sanatsal sese kulak vermelerine katkısı olmuştur" (Gombrich, 1980: 403-404). 19. yüzyılın ortalarından sonra, on yıl süren sanat hareketlerinin desteği ile üretilen görseller, kendilerini akademik gelenekten kurtarmıştır. Manet'nin Olympia'sı (183283) bu dönemde ideal kadın imgesinde görülen içerik değişikliğine dair iyi bir örnek oluşturmaktadır. Olympia, müşterileri tarafından gönderilen çiçekleri zenci uşağı aracılı̆̆ı ile kabul eden bir hayat kadınıdır. İdeal kadın imgesi, Venüs betimlemelerinde genelde rastlanan çıplaklıkta olmasına karşın, artık kutsal içerikli ya da ideal ölçü ve perspektifte değildir. Bu tabloda Olympia daha önce resmedilen nü figürlerden değişik olarak direkt olarak izleyicinin gözlerinin içine bakmaktadır (Beazley, 2000: 111). Manet'nin Olympia'sı, kadının toplumsal değerinin değişmekte olduğunun farklı bir yorumu olarak görülebilir.

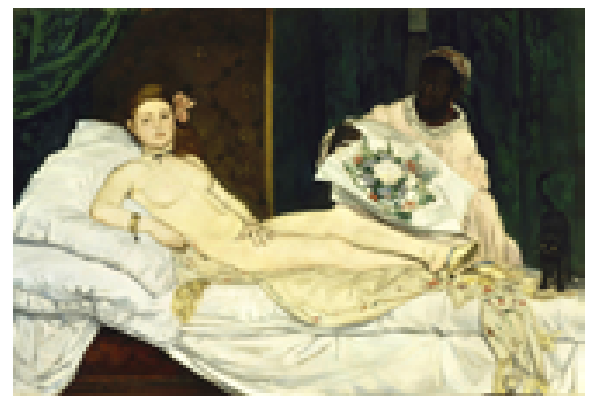

Resim 4: Eduard Manet, Olympia, I863, Tuvale Yağlı Boya,30,5 x $190 \mathrm{~cm}$

Modern sanatta, çıplaklık kategorisi daha az önemli hale gelmiştir. Sanatçıların kendisi bile bunu sorgulamaya başlamıştır. Diğer pek çok açıdan olduğu gibi, bu açıdan da, Manet'nin eserleri bir dönüm noktasını temsil eder. Onun Olympia'sı ile Titian'ın orijinal çalışması karşılaştırılacak olursa, geleneksel bir role bürünmüş, o rolü biraz da cüretkâr bir biçimde sorgulayan bir kadın görülecektir. İdeal yıkılmıştır, ancak bu idealin yerini alabilecek fazla bir şey de yoktur; erken avangard, 20. Yüzyıl resimlerindeki tipik kadın haline gelen fahişenin realizmi dışında (Toulouse- Lautrec, Picasso, Rouault, Alman ekspresyonizmi). Akademik resim alanında ise gelenek devam etmiştir (Berger, 1972: 63-64).

Yine modern çağda, Picasso'nun kadın formları, ilkel sanat formlarından, Afrika sanatından etkilenmiştir. Kullanılan figürler, görsel olarak ilkel çă̆ kadın görselleri ile benzerlik gösterse dahi, kadınları doğurganlık sembolü olarak resmeden atalarımızdan farklı olarak, modern kültürün kadın görüntüsünü, bakana zevk verir unsurlardan uzak bir biçimde işlemiştir 
(Beazley, 2000: 114).

Kadın figürlerinin kullanımının başlangııından itibaren, paleolitik çağdan, moderniteye kadar, döngü, başladığı noktaya görüntü bakımından geri gelmektedir. Fotoğrafın (1833) ve silindirli rotatif baskı makinesinin (1843) keşfiyle, sanatçılar, fotoğraf gerçekliğinde sunumlar yansıtmayı bırakmış, formun kendisini yeniden yorumlamaya çalışmışlardır. Özellikle, rötuşlu fotoğraflarla, ideal kadınimgesinin metalaştıııması söz konusu olmuştu. Bu gelişmelerin, görüntünün kendisinin takas edilebilir ve çoğaltılabilir bir ürün haline gelmesine neden olduğu düşünülebilir.

\section{Çağdaş İdeal Kadının İmgesi}

"Özellikle sanayi devriminden sonra, teknoloji; zamanın, sosyo ekonomik ve kültürel koşulları üzerinde çok önemli etkiye sahip olmuştur. Devrim, Birleşik Krallıkta başlar, daha sonra Avrupa'ya, Kuzey Amerika'ya ve nihayetinde tüm dünyaya yayılır" (Stickland, 1992: 89).

Teknolojinin yaygın kullanımı, üretim, taşımacılık ve tüketim anlamında tüm dinamikleri hızlandırmıştır. Bunun yanında, buhar gücünün endüstriyel matbaacılık süreçlerine uygulanması, gazetelerin ve popüler kitap dağıtımının muazzam biçimde yayılmasını desteklemiştir.

Her türden görüntünün seri üretimine ve dağıtımına olanak sağlamıştır; bunun sonucunda sanat çalışmaları gizemli havasını, aurasını ve emsalsiz olma özelliğini kaybetmiştir. Tüm malların seri üretimi ve tüketimi söz konusu olmuştur. Sanat çalışmalarının özdeş baskıları yapılmaya ve satılmaya başlamış, öyle ki, kendileri dahi ticari mal haline gelmiştir. Popüler kültür ve popüler sanat dünyaya yüzünü göstermeye başlamıştır (Hobbs, Duncan, 1992: 486).

Bu süreçte, o günün ihtiyaçlarının bir parçası ve gereği olarak başka bir imgekullanımortamı ortaya çıkmıştır; bu da reklamcılıktır.

19. Yüzyılda, ekonomi genişlerken, reklamcılık da beraberinde genişlemiştir. Yüzyılın sonunda, kadınlar için iş dünyasında kariyer seçenekleri arasında, reklamcılık az sayıdaki seçenekten biri olmuştur. Kadınlar evdeki alışverişin büyük bölümünden sorumlu olduklarından, reklamcılar ve ajanslar yaratıcı süreçte kadının düşüncelerinin değerini fark etmişlerdir. Kadın görüntüsünün satış gücünden yararlanılan ilk Amerikan reklamı bir sabun reklamıdır. ${ }^{2}$

${ }^{2}$ Charbel Farah, Beirut, Le. (Temmuz, 2015). Ad Age Advertising Century: TimelineA 295-Year Synopsis of theMostlmportantEvents in AmericanAdvertising, I704 to 1999. Web: http://adage. com/article/special-report-the-advertising-century/ad-age-advertising-century-timeline//4366 I adresinden 27 Temmuz 2015' te alınmıştır. 
Bu reklamlar, ideal kadın imgesinin dönüşüm noktalarından biri olmuştur. $\mathrm{O}$ zamandan başlayarak kadın imgesi ticaretin bir parçası ve tüm zamanların en fazla seri üretimi yapılan görüntüsü olmuştur. Bu sefer, dini ya da akademik nitelikleri kapsamında değildir, bir cinsel nesne, bir arzu nesnesi olarak kullanılmaktadır (Berger, 1972: 144).

Cinselliğin, çağımız görsel kültüründe doğrudan ya da dolaylı olarak öne çıkmakta olduğu düşünülebilir. Kapitalist ekonominin aktif bir kolu olarak reklamcılık, kadın görselliğini bir arzu nesnesi haline getirir. Nesneleştirme, daha önce hiç bu kadar abartılmış olmamakla beraber kadın imgesinde mükemmel görünme ihtiyacını doğurmuştur. Jean Baudrillard bu durumu şu şekilde dile getirir:

Tüketicinin paketinde bir şey var ki diğer hepsinden daha iyi, daha kıymetli ve daha büyüleyici ve hatta tüm bunları içinde topladığı gerçeğine rağmen otomobilin dahi olduğundan daha fazla çağrışım ile yüklü. Bu şey BEDEN. Bin yıllık bir birPrutanism çağının ardından fiziksel ve cinsel özgürleşme ruhuyla vücudun yeniden keşfi, reklamcılığın, modanın ve kitle kültürünün her yerinde oluşu (özellikle de kadın vücudunun her yerde oluşu, açıklamaya çabalamamız gereken bir gerçek), onu çevreleyen hijyenik, diyetetik, tedavi edici kült; gençliğe, zarafete, erkekliğe/ kadınlığa, tedavi ve diyetlere olan takıntı ve ona bağlı fedakarca eylemler hepsi, bugün bedenin artık bir kurtuluş nesnesi olduğu gerçeğinin birer göstergesidir (Baudrillard, 1970: 129).

1980'lerde, ideal kadın imgesi, mükemmel kadın imgesiyle eşleşmiş ve günlük hayata yerleşmiştir. Söz konusu imge artık sadece bir reklam ya da moda resmi değildir. Kadının kendisi, günlük yaşamda yer almak için mükemmel görünmek zorundadır. Diğer bir deyişle, mükemmel kadın, resmi kadının kendisine yaftalanmıştır.

Mükemmel vücut ve yüzün birleşimi olarak modern kadın imgesi, sadece bir temsil öğesi ya da kadının ticari bir meta olarak nesneleştirilmesinin bir işareti değil, aynı zamanda sıradan bir kadının iş bulabilmesi ve toplumda yer alabilmesi için de bir gereklilik olarak kendini göstermeye başlamıştır. Yine, hergün gazetelerde görülen münhallerin pek çoğunda yer alan "presentable" koşulunun çerçevesi, kitlesel medya tarafından çizilmektedir. Kitlesel medya ve reklamcllık, reklam görüntülerinde kullanılan modeller kadar ince ya da güzel olmayan kadınlar için güzellik standartlarını diretir. $\mathrm{Bu}$ diretme, kapitalist ekonomi açısından aynı zamanda, belirli diyet ürünlerinin ve kozmetik ürünlerinin bir ömür boyu tüketiminin de bir ısrarı ve bu sektörlerde büyümeyi, kar yapmayı sürekli kılmanın doğrudan bir çabası olarak görülebilir. 
Günümüz ideal kadın imgesi standartlarını yakalamak ve bunları muhafaza etmek son derece zor bir uğraş sürecini gerektirmektedir. İdeal kadın görüntüsü, birleşik pazarlama stratejisi açısından öyle bir hale getirilmiştir ki, söz konusu özelliklere erişmek, pek çok modern kadın için ömürlük bir mücadele gerektirmektedir. Günümüz ideal kadın imgesi, buna bağlı gelişen güncel görüntünün karakteri ve bu görüntünün günlük yaşam pratiklerine yansımaları, bilimsel platformda ortaya çıkan yeni gelişmelerin uzantısı olarak kendini gösterebilir. Yeni bilimsel keşifler ve buna bağlı teknolojiler, mükemmel görünme mücadelesindeki bir kadının ihtiyaçlarına cevap niteliğini almakla kalmaz, aynı zamanda bu çalışmada yer alan tartışmanın başından beri sözü edilen çevreleyen ve şekillendiren unsurlardanbiri haline dönüşebilir.

Tüm bu koşullara bağlı olarak gelişen yaşlanma karşıtlı̆̆ı alanı, insanların, vücut durumlarını ve yaşam tarzı tercihlerini kontrol altında tutarak, daha uzun ve sağııkı yaşayabilecekleri iddiası ile buna bağlı bir takım tıbbi uygulamalar geliştiren bir alandır. Zamanla, "yaşlanma karşıtlığı ve yaşlanmayı önleme" toplumsal bir hareket halini almıştır. Yaşlanmayı önleme hareketi ilk olarak 1990'larda yaygınlaşmaya başlamıştır. Bu başlangıçtan itibaren, "yaşlanmayı önleme"; tıp, çare, endüstri, çözüm, formülasyon, terapi, kozmetik, hormon, vitamin, hap, ilaç, reçete, diyet, egzersiz, test, teknik gibi kelimelerle birlikte medyada anılmaya başlar.

Yaşlanma karşıtlığı, medya vasıtası ile ilgili ürünlerin dolaşımını sağlayarak yukarda bahsedildiği gibi sunulsa da, aslında, bilim dünyasında yansıması başlangıç olarak, Rudman'ın, büyüme hormonunu yetişkinlerde yaşlanmayı on ila yirmi yıl arasında geciktirmek için kullandığı çalışmasına dayanmaktadır. $\mathrm{HGH}$, bir insanın büyüme evresinde hipofiz bezi tarafından salgılanan bir hormondur. Bu evrenin sona ermesinin ardından, beynin alt kısmında, burnun arkasında yer alan bu salgı bezi, hormonu vücuda yaymayı durdurur. Rudman'ın çalışmasının ışığında, ecza devi Eli Lillybir aminoasit zincirini insanın büyüme hormonu ile sentezleyerek, büyüme hormonunun salgılanması durduktan sonrada kullanılabilir hale getirmiş ve "Humatrope" üretilmiştir (Myktyn, 2010: 2).

1990-2010 arası, yaşlanmayı önleme bilimsel-biyomedikal-alanları olağanüstü düzeyde büyüyerek tam bir araştırma ve uygulama sahasına dönüştü. Sözkonusu süre aralığında, binlerce yaşlanmayı önleme medikal klinik, yaşlanma karşıtlığı fikirlerinin yayılmasına adanmış kuruluşlar, buna bağlı operasyonlar üzerine üniversitelerde çalışan araştırmacılar ve biyoteknoloji firmaları, ürünleri pazarlayan şirketler ortaya çıkmıştır (Mykytyn, 2010: 183). Mykytyn'nin deyimiyle, tüm bu gelişmeler aynı zamanda, tıbbi bir esasa dayanan bir "mükemmellik kültürü" oluşmasına yol açtı (Myktyn, 2010: 185). 
Bilim platformunun bir bölümü için, insan ırkının geleceğinde büyük değişimlereyol açabilme potansiyelini taşıması sebebi ile yaşlanma karşıtlığı/ yaşlanmayı önleme fikri, olağanüstü ve gelecek vaat eden niteliktedir. Yaşlanmanın olmadığı bir gelecek, özgürleşmekle eşdeğerdir, artık "mutlak bir son" düşüncesi olmaksızın var olunabilecektir. Bu potansiyel, alandaki yatırımların ve çalışmaların ışık hızıyla gelişmesine olanak sağlamıştır, artan ilgi ve finansal destek elle tutulur sonuçların ortaya konmasını da beraberinde getirmiş̧ir, örneğin moleküler biyolog CynthiaKenyon, yaşı kontrol eden genlerinmanipülasyonuile solucanların yaşam sürelerini iki katına çıkartmayı başarmıştır (Kenyon, 1993: 2). Takip eden çalışmalarında ise Kenyon, gen manipülasyonuna ek olarak sürdürülecek ve ömür boyu sürecek bir tür diyetin yaşam süresini ve dahası, kalitesini artıracağına yönelik çalışmaları yine solucanlar üzerinde gerçekleştirmiştir (Kenyon, 2005:119-128). Aynı zamanda, bu diyete bağlı kalınan bir yaşamın kanser, şeker hastalığı ve alzheimer gibi hastalıkların oluşum yüzdesini düşürdüğg̈ iddia edilmektedir.

Popüler medya, bu alanı 1996 yılı dolaylarında keşfeder. Pazarlama ve reklamcılık sektörü, alanın taşıdığı potansiyeli kısa zamanda farketti çünkü alana bağlı büyük miktarda ürün ve hizmetler bulunmakta idi. Tüm bunlara ilave olarak "yaşlanmayı önleme söylemi" bilim insanlarının doğrulayan görüşleri kapsamında yasal ve geçerli olarak yansıtılmıştı.Yoğun pazarlama stratejileri sonucu beş yıl içersinde, tüketiciler tarafından yaşlanmayı önlemek için bir yılda harcanan para bir milyar dolara ulaşmıştı. Tüm bu satış odaklı hareketlerin yansıtıldığı ticari şeklin yanında, bilim dünyasının yaşlanmayı önleme hakkındaki fikrine yaklaşımı hala kuşkulu idi. Ana akım, bilim adamları açısından deneylerle desteklense de, ilgili gibi görünen ürünler hala fanteziydi ve bu fikirle ilişkili ürünler hala Amerikan Gıda ve İlaç Kurumu tarafından onaylanmamıştı (Myktyn, 2010: 186).

Alanın etkisi altında şekillenen ideal kadın imgesi ile alakalı çarpıcı nokta, son dönem ideal kadın görsellerinin daha evvel reklamlarda kullanılmış olan kadın imgelerinden çok farklı bir görsellik sergilemekte olduğudur. Son dönem kozmetik ve makyaj ürün reklamlarında kullanılmakta olan ideal kadın imgeleri seksi, renkli, parlak, çarpıcı, çekici değildir. Bu imgelerin daha ziyade steril, muhtaç, izole bir yapı taşıdığı gözlenebilir.

1970-80 dönemi reklamlarında kadın imgesi çekici ve süslüdür, bunların yanı sıra bu dönem reklamlarında "ünlü yüz" kullanımı, yani zaten seksapeli ve imajı kabul edilmiş kadınların reklamlarda kullanımı yaygındır. Buna karşılık olarak 1995 sonrası, yaşlanma karşıtlığı söylemi ile paralel gelişen ideal kadın imgesi tüm bu süs ve ünden arınmıştır. İmgeler, üzerlerinde yaşlanma karşıtı söyleminin kendi içerisinde barındırdığı "bilimsel" kalıbın 
ve dokunun görsel bir versiyonunu taşırlar. Steril, ifadesiz, süssüz reklam görüntüsü, marka ayrımı gözetilmeksizin, dönemin tüm reklamlarında benzer şekilde kendisini gösterir.

Bu kapsamda, artık ideal kadın imgesi, (tarihi süreçte olduğu gibi), verimliliği, ruhaniliği ya da mitolojiyi yansıtmamaktadır, daha ziyade tam bir durağanlığı, aydınlanma hareketinin amacına paralel şekilde "işlevsel olarak kontrolü" yansıtmaktadır. Adorno ve Horkheimer'ınifadesine göre aydınlanma hareketinin amacı "insanoğlunun korkudan azat olması ve kendi egemenliğini kurması" doğa üzerinde hâkimiyetidir. Bir başka deyişle hiçbir şey kontrol dışında kalmamalıdır çünkü herhangi bir olgunun insanoğlunun kontrolü dışında gelişmesi vevar olması fikri insanoğlu için güçlü bir korku kaynağıdır. Böyle bir amaca ulaşabilmek için her şey bilinmeli, hiçbir şey bilinmeyen olarak kalmamalıdır, dolayısı ile "bilgiye" dönüşemeyen kavramlar ve nesneler, pozitif bilim tarafından elenmelidir yani çağımızda mit ya da hikayelere yer yoktur. Bu, insanın kurtuluşunun ve doğa üzerine hâkimiyetinin anahtarıdır (Adorno ve Horkheimer, 1976: 8-15).

\section{Sonuç}

Bu araştırmada, tarih sürecinde kadın imgesi üzerine, baskın toplumsal değerler/imge karşılaştırması yapılmıştır. İdeal kadın imgesinin, şekil ve form bakımından, dönemlere göre gösterdiği değişimlerin, döneme ait toplumsal değerler ve teknolojik olanaklar doğrultusunda şekillendiğisonucuna ulaşılmıştır. Anlamlandırma ve görseli okuma sürecinde yine toplumsal değerler doğrultusunda anlam ve içerik değişikliği sergilediği görülmüştür.

Araştırmada ortaya konan, eser/ içerik/ dönem değerleri karşılaştırmasında, kadın imgesinin değişimi ve bu değişimi oluşturan etkiler zaman aralıklarına göre dizilmiştir. Söz konusu dizin, Paleotitik dönemden günümüze, görsel biçimi bakımından büyük değişiklikler gösteren ideal kadın imgesinin dönüşümününsebepleriniortaya koymuştur. M.Ö. 20000 ve6000arasında, kadın imgesinin doğa ile mücadele, beslenme ve üreme mecburiyetleri doğrultusunda şekillendiği ortaya konmuştur. Takip eden 5000 yıl boyunca iyileşen yaşam koşulları ve pagan inanışları çerçevesinde, mitolojik kimlikleri ile daha detaylı bir biçimde görselleştirildiği görülmüştür. Erken orta çağda, hıristiyan kilisesinin etkisi altında kimlik ve isim bakımından tekilleştiği, form bakımından boyutunu kaybettiği ve daha önce yüzyıllar boyu sergilediği çıplaklıktan arındığı gözlenmiştir. Rönesans dönemine gelindiğinde, çıplaklığın, grekoromen stili ve dönemin beraberinde getirdiği teknolojik olanaklarla tekrar yoğrularak görsel biçim ve kimlik bakımından çeşitliliğini geri kazanmaya başladığı görülmüştür, ancak "kutsal" anlamını 
hâlâ barındırmaktadır. Modern dönemden başlayarak dini kapsam ve anlamından büyük ölçüde sıyrıldığı ve gelişen teknolojik ve bilimsel etkiler altında ticari imge olarak şekillendirildiği örneklerle gösterilmiştir.

Bu kapsamda, görsel sanatlarda, herhangi bir işaretin, sembolün ve imgenin anlamı kronolojik dizindeki konumuyla ilişkili şekil ve içerik değişiklikleri gösterdiği sonucuna varımıştır. İşaret olarak kadın imgesinin, çevresinde bulunan komşu birimlere bilinçli göndermeleri olduğu gözlemlenmiştir. Döngü içerisinde, işaret, bu birimlerle birlikte yapılandırılmakta ve aynı zamanda yapı elemanlarından biri haline dönüşmektedir. 


\section{Kaynakça}

Baudrillard, J. (1970). Consumer Society, Myths and Structures, Paris: Edition Denoel.

Barthes, R. (1957). Mythologies, Paris: Seuil.

Beazley, M. (2000). Understanding Paintings, London: Octopus Publising.

Berger, J. (1972). Ways of Seeing, London: Penguin Books.

Eco, U. (2006). Storia della Belleza, Milano: Bompiani.

Gilbert, R. (1998). Living With Art, Ohio: McGraw Hill.

Gimbutas, M. (1989). The Language of the Goddess, London: Thames and Hudson.

Gombrich, E.H. (1980). The Story of Art, London: Phaidon.

Günay, D. (2008). “Görsel Okuryazarlık ve Imgenin Anlamlandırılması”, SDÜ Arte-Güzel Sanatlar Fakültesi Sanat Dergisi, Cilt (I), I-29.

Horkheimer, M. and Adorno. T. (1976). Dialectics of Enlightenment, USA: Paperback Edition

Hobbs, J. and Duncan, R. (1992). Arts, Ideas and Civilization, New Jersey: PrenticeHall.

Kenyon C. Jean C. Erin G. Adam R. and Ramon T. (1993) "A C. elegans mutant that lives twice as long as wildtype."Nature, Cilt(366), 46I-464.

Kenyon C, Hansen M, Dillin A. (2005). "New genestied to endocrine, metabolic, and dietary regulation of lifespan from a Caenorhabditis elegans genomic RNAi screen"PLoSGenet, Cilt(I), I I9-I28.

Mykytyn, C. (2010). "A History of the Future: The Emergence of Contemporary Anti-Ageing Medicine", Sociology of Health and Ilness Cilt(32), I8I-196.

Saussure, F. (1966). Course in General Linguistics, Illınois: McGraw Hill Book Company.

Strickland, C. (1992). The Annotated Mona Lisa, Kansas City A Universal Press Syndicate Company.

\section{İnternet Kaynakları}

Charbel F.Beirut, Le. (Temmuz, 2015). Ad Age Advertising Century: TimelineA 295-Year Synopsis of theMostlmportantEvents in AmericanAdvertising, I704 to 1999. Web: http:// adage.com/article/special-report-the-advertising-century/ad-age-advertising-centurytimeline/I4366I adresinden 27 Temmuz 2015' te alınmıştır. 
Columbia Electronic Encyclopedia. (February, 2013), 6thEdition; pl, Venusin Roman religion and mythology. Web: http://connection.ebscohost.com/c/reference-entries/85548764/ venus-roman-religion-mythology adresinden 15 Haziran 2015'te alınmıştır.

\section{Görsel Kaynakları}

Resim I: http://www.myartprints.co.uk/a/anonymous-painter/the-venus-of-willendorf-f. html

Resim 2: http://arounddeglobe.com/hagia-sophia-greatest-example-byzantinearchitecture/

Resim 3: http://www.uffizi.org/artworks/the-birth-of-venus-by-sandro-botticelli

Resim 4: http://www.arthistoryarchive.com/arthistory/manet/arthistory_manet.html 
